Article

\title{
Monitoring Coral Health to Determine Coral Bleaching Response at High Latitude Eastern Australian Reefs: An Applied Model for A Changing Climate
}

\author{
Steven J. Dalton * and Andrew G. Carroll
}

National Marine Science Centre, Southern Cross University, PO Box 4321 Coffs Harbour, NSW 2450, Australia; E-Mail: acarroll@nmsc.edu.au

* Author to whom correspondence should be addressed; E-Mail: sdalton@nmsc.edu.au; Tel.: +61-02-6648-3927; Fax: +61-02-6651-6580.

Received: 5 July 2011; in revised form: 17 August 2011/ Accepted: 22 September 2011/ Published: 30 September 2011

Abstract: Limited information is available on the bleaching susceptibility of coral species that dominate high latitude reefs along the eastern seaboard of Australia. The main aims of this study were to: (i) monitor coral health and spatial patterns of coral bleaching response at the Solitary Islands Marine Park (SIMP) and Lord Howe Island Marine Park (LHIMP), to determine variability of bleaching susceptibility among coral taxa; (ii) predict coral bleaching thresholds at $30^{\circ} \mathrm{S}$ and $31.5{ }^{\circ} \mathrm{S}$, extrapolated from published bleaching threshold data; and (iii) propose a subtropical northern New South Wales coral bleaching model from biological and physical data. Between 2005 and 2007 minor bleaching was observed in dominant coral families including Pocilloporidae, Poritidae and Dendrophylliidae in the SIMP and Pocilloporidae, Poritidae and Acroporidae (Isopora and Montipora spp.) in the LHIMP, with a clear difference in bleaching susceptibility found between sites, both within and between locations. Bleaching susceptibility was highest in Porites spp. at the most offshore island site within the SIMP during summer 2005. Patterns of subtropical family bleaching susceptibility within the SIMP and LHIMP differed to those previously reported for the central Great Barrier Reef (GBR). These differences may be due to a number of factors, including temperature history and/or the coral hosts association with different zooxanthellae clades, which may have lower thermal tolerances. An analysis of published estimates of coral bleaching thresholds from the Caribbean, South Africa, GBR and central and northern Pacific regions suggests that the bleaching threshold at $30-31.5{ }^{\circ} \mathrm{S}$ ranges between $26.5-26.8{ }^{\circ} \mathrm{C}$. This predicted threshold was confirmed by an extensive coral 
bleaching event on the world's southernmost coral reef at Lord Howe Island, during the 2010 austral summer season. These results imply that dominant coral taxa at subtropical reefs along the eastern Australian seaboard are highly susceptible to thermal stress; which, in turn, could lead to a future decline in total live coral cover if predicted rising seawater temperatures lead to more frequent coral bleaching events in future.

Keywords: coral bleaching; bleaching thresholds; subtropical scleractinian corals; thermal stress

\section{Introduction}

The recent increase in coral bleaching occurrence and severity has resulted in a substantial decline in live hard coral cover on many coral reefs throughout the world [1-3]. Coral bleaching has been described as the dissociation of the symbiotic relationship between zooxanthellae and their cnidarian host, and/or a reduction in photosynthetic pigment concentration as a result of stress [4-6]. Stress may result from a number of factors including: changes in salinity [7-9]; solar radiation (including ultraviolet radiation) [10-12]; pollution [13]; change in seawater temperature [4,6,12,14]; or diseases [15-17]. Moreover, the combined effect of increased seawater temperature coinciding with recent strong El Niño-Southern Oscillation (ENSO) events and periods of high light intensity has caused unprecedented bleaching episodes on a global scale. With seawater temperature predicted to rise, mass-bleaching events will continue, which may result in the loss of many ecologically and economically important habitats [2,18,19].

Coinciding with a higher than normal sea surface temperature (SST) anomaly during the 1997-1998 ENSO event, coral bleaching was reported at high latitude subtropical reef regions along the east coast of Australia, including World Heritage listed Lord Howe Island and throughout the Solitary Islands Marine Park (SIMP; [20]). Quantitative surveys conducted at Lord Howe Island Marine Park (LHIMP) four months after initial bleaching found that many dominant coral species, including Isopora cuneata, Pocillopora damicornis, Porites spp. and Stylophora pistillata were recovering from pigmentation loss [21]. Additionally, during surveys conducted in the SIMP in summer 1998, many corals from the families Acroporidae, Pocilloporidae and Dendrophylliidae were observed with a noticeable reduction in symbiotic algae pigmentation [20].

Scleractinian corals have an upper thermal threshold and when this is exceeded, bleaching may occur [2]. This threshold varies over geographical and seasonal scales, according to adaptation (over thousands of years) and acclimatization (seasonal changes) responses to local yearly maximum and seasonal temperature trends [22]. For example, Berkelmans and Willis [22] indicated that winter bleaching of $P$. damicornis on the central Great Barrier Reef (GBR) occurred at temperatures $1{ }^{\circ} \mathrm{C}$ below summer thermal maximum values, which may reflect differential temperature susceptibility according to previous short- and long-term temperature history.

The aims of this study were to: (i) monitor coral health to determine the relationship between seawater temperature and spatial patterns of bleaching within the coral communities at the SIMP and LHIMP; (ii) determine the variability of bleaching susceptibility among coral taxa at these locations; 
(iii) predict coral bleaching thresholds at $30^{\circ} \mathrm{S}$ and $31.5^{\circ} \mathrm{S}$, extrapolated from published bleaching threshold data from northern locations and in situ bleaching data collected during this study; and (iv) propose a subtropical northern New South Wales (NSW) coral bleaching model from biological and physical data.

\section{Methods}

\subsection{Study Site}

The SIMP $\left(30{ }^{\circ} \mathrm{S}, 153{ }^{\circ} \mathrm{E}\right.$, Figure 1), located on the east coast of northern NSW and LHIMP $\left(31.5{ }^{\circ} \mathrm{S}, 159{ }^{\circ} \mathrm{E}\right.$, Figure 1), which lies approximately $600 \mathrm{~km}$ east of mainland Australia, have previously been recognized for their high scleractinian coral cover [23-26]. Criteria for site selection in this study included similar depth gradients and relatively homogenous cover of benthic assemblages with a clear dominance of scleractinian corals. Four island associated reefs (10-15 $\mathrm{m}$ depth) within the SIMP and four sheltered (2-5 m depth) and two exposed (10-15 m depth) sites at LHIMP, were randomly selected within areas of high coral cover to monitor coral health and bleaching response between 2005 and 2007 (refer to [27] for additional site descriptions).

Figure 1. Location of the Solitary Islands Marine Park (SIMP) and Lord Howe Island Marine Park (LHIMP) northern New South Wales, Australia: (a) SIMP (grey shaded area) - two sites were located on the north-western side of four islands: North Solitary Island (NSI), North West Solitary Island (NWSI), South West Solitary Island (SWSI) and Split Solitary Island (SSI); (b) LHIMP (grey shaded area) - four lagoon and two exposed sites were surveyed during May 2005.

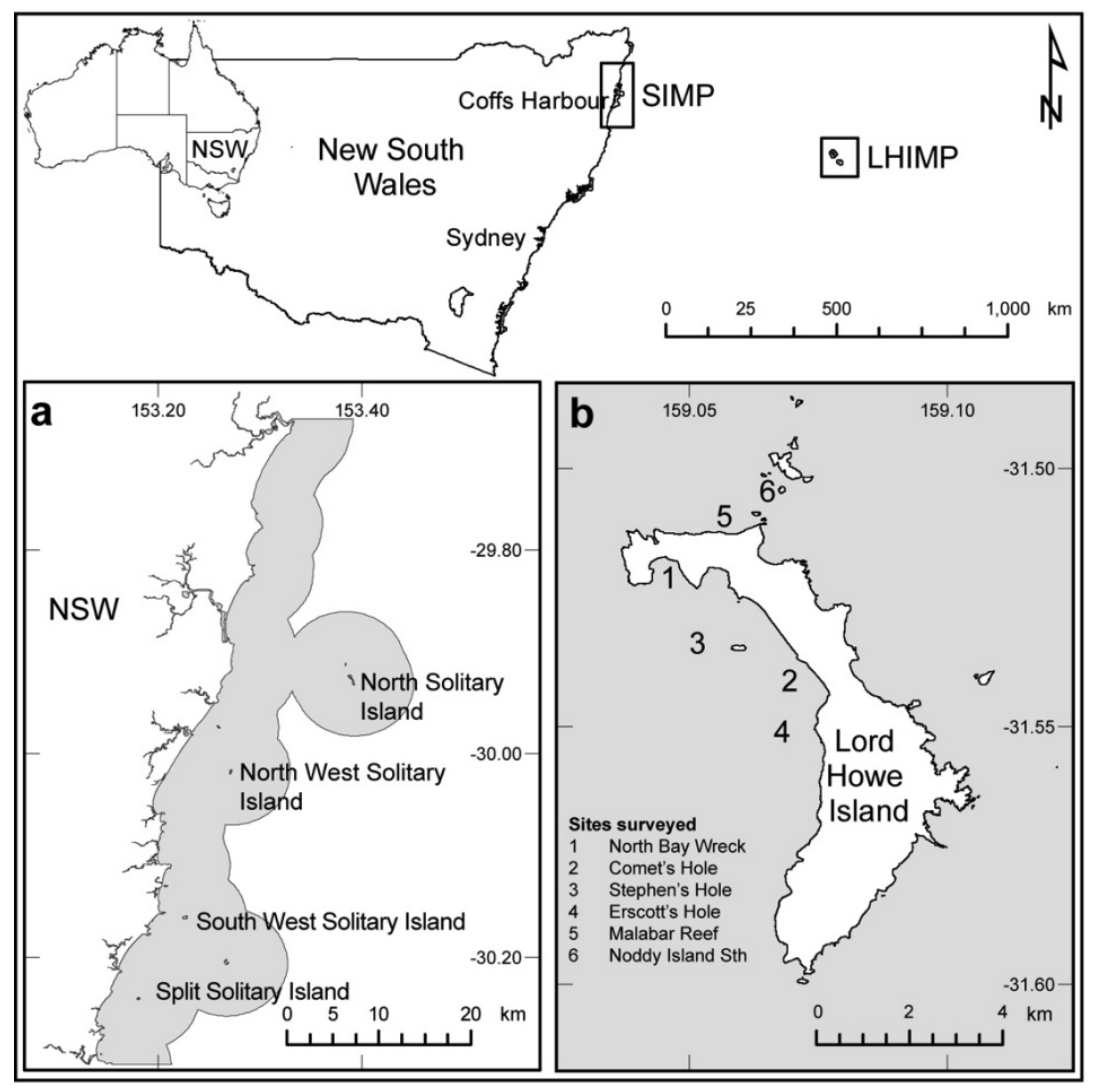




\subsection{Coral Health and Bleaching Response}

Coral health and bleaching response assessments were completed in conjunction with Australian subtropical white syndrome (ASWS) evaluations within the SIMP between 2005 and 2007 and at LHIMP in 2005 [27]. Coral health surveys were conducted adjacent to four islands within the SIMP (Figure 1a) during March each year, which corresponded to the period of warmest seawater temperatures. Sampling at LHIMP was completed at four lagoon and two exposed sites (Figure 1b) during May, when seawater temperature ranged between $21-22^{\circ} \mathrm{C}$.

Five 20-metre fiberglass tapes were randomly placed on the benthos within $30 \times 30 \mathrm{~m}$ permanent sites, (GIS referenced to enable relocation) and corals larger than $50 \mathrm{~mm}$ occurring within one meter either side of the tape were evaluated for signs of recent stress, which included stress caused by biotic (disease and predation) and abiotic (sediment abrasion and thermal bleaching) factors. Individual corals were recorded as bleached according to pigmentation color characteristics. Prior to assessment dives, all coral species observed at each study site were compared to the Coral Health Monitoring Chart (CHMC; 28) and normal pigment color was calibrated with the color chart codes. These codes were used as a reference during all subsequent coral health surveys. If a colony displayed white, patchy white or pale coloration, relative to normal pigmentation of that coral species at that location, then the individual coral was recorded as either moderately (1-50\% tissue bleaching) or severely (51-100\% tissue bleaching) bleached, according to either the percentage of colony discoloration and/or the level of pigment paling (consistent with [28,29]).

\subsection{Seawater Temperatures}

Hastings Tidbit Stowaway temperature loggers were deployed at North Solitary and South West Solitary Islands within the SIMP at a depth of $10 \mathrm{~m}$. These loggers recorded in situ temperature data every 30 min between 2000 and 2006. These loggers were replaced with Dataflow Odyssey loggers in early 2006. The loggers were removed annually and temperature data downloaded before being re-calibrated and replaced at each site (see [30] for further description). During this period similar devices were not deployed at LHIMP; therefore as a proxy for in situ temperature, satellite derived sea surface temperature (SST) data were acquired from the National Oceanic Atmospheric Administration (NOAA) and descriptive statistics and Maximum Monthly Mean (MMM) climatology determined between 2001 and 2007 for LHIMP. NOAA reef watch program utilize bleaching thresholds $1{ }^{\circ} \mathrm{C}$ above MMM to predict bleaching events [31].

\subsection{Statistical Analysis}

\subsubsection{Coral Bleaching Response}

Prior to analyses, the proportion of each bleaching category (i.e., the number of colonies within each bleaching category divided by the total number of corals within each transect) were calculated for all coral taxa. A single scaled measure bleaching susceptibility index (BSI) was calculated for total coral and coral family from each replicate transect using a modification of the bleaching index formula given in McClanahan et al. [28]; only three categories were utilized in this study, because mortality 
associated with bleaching could not be accurately quantified. Bleaching susceptibility index was calculated using the formula:

$$
\mathrm{BSI}=(0 \mathrm{un}+1 \mathrm{mb}+2 \mathrm{sb}) / 2
$$

where proportional data from unbleached (un), moderately bleached (mb) and severely (sb) bleached categories were utilized. This formula appropriately weighted each category to account for increased stress resulting from greater pigmentation loss.

Patterns of BSI within the SIMP coral community were analyzed using a factorial ANOVA with the Minitab statistical package. Prior to analysis, BSI data were tested for normality and homogeneity of variance and, where necessary, root arc-sin transformed. To determine the difference in coral family bleaching susceptibility, family BSI data from the SIMP and LHIMP were analyzed using factorial ANOVAs. Student-Newman Keuls (SNK) tests were performed on each dataset to explore further differences between families within sites, and within families between sites.

\subsubsection{Predicting Subtropical Bleaching Thermal Threshold}

Linear and second-order polynomial regression models (Graphpad Prism v5.0) were fitted to published thermal threshold data from tropical and other subtropical locations [2,32]. Comparing these models indicated that the quadratic model was a more accurate fit of the data; hence this model was used to extrapolate a theoretical bleaching threshold for the SIMP and LHIMP coral communities. This index was then compared to in situ and SST datasets to propose a coral bleaching threshold hypothesis for the eastern Australian subtropical region, and estimate the minimum period of exposure to thermal stress required to induce a thermal bleaching response in subtropical scleractinian coral communities.

\section{Results and Discussion}

During this study, a severe coral bleaching event was reported throughout the southern GBR (2005-2006), however no increased bleaching response was recorded south of $25.5^{\circ} \mathrm{S}$, along the east coast of Australia. At the time of this episode, a large pocket of warm water $\left(2{ }^{\circ} \mathrm{C}\right.$ above early summer MMM) lay along the southern GBR coast (approx. 20-24 ${ }^{\circ} \mathrm{S}$, [33]) for several months. Northward-flowing cooler water restricted the movement of this warm seawater body south of Fraser Island, Queensland (approx. $25^{\circ} \mathrm{S}$ ). In situ seawater temperature within the SIMP during this period only exceeded $27{ }^{\circ} \mathrm{C}$ on three occasions at NSI (February 5th, 6th and 22nd 2006). Monitoring the health and bleaching response of corals on SIMP and LHIMP reefs between 2005 and 2007 confirmed that severe bleaching did not occur; however there was evidence of differential bleaching susceptibilities amongst coral families and within the coral communities examined.

\subsection{Patterns of Bleaching Response in the SIMP}

A total of 83,951 individual coral colonies were counted at the eight sites investigated between 2005-2007, of which 2,950 and 138 colonies were recorded as moderately and severely bleached, respectively. Overall, the proportion of total bleached coral colonies (moderate and severe categories combined) within each location varied between 4 to $16 \%$ during all summer surveys. The highest proportion of colonies noted as moderately bleached was recorded during summer 2005 (11\% pooled 
from all sites); however severe bleaching was greatest during summer $2006(<1 \%$ pooled from all sites). Total bleaching response was highest at Anemone Bay (NSI) during summer 2005, where 22\% and $1 \%$ of coral colonies were observed with moderate and severe bleaching response, respectively. At the other sites, moderate and severe bleaching ranged between 6 and $<1 \%$ (SSI-Coral Corner) and 12 and 1\% (NSI-Trail Mooring), respectively. Total bleaching response during summer was highest at NSI compared to the more southern nearshore island reefs (Figure 2).

Figure 2. Average proportion ( $\mathrm{n}=5$ belt transects per site) of moderate (dark grey) and severe (light grey) coral bleaching categories recorded at eight island reefs within the SIMP, surveyed in summer 2005-2007.
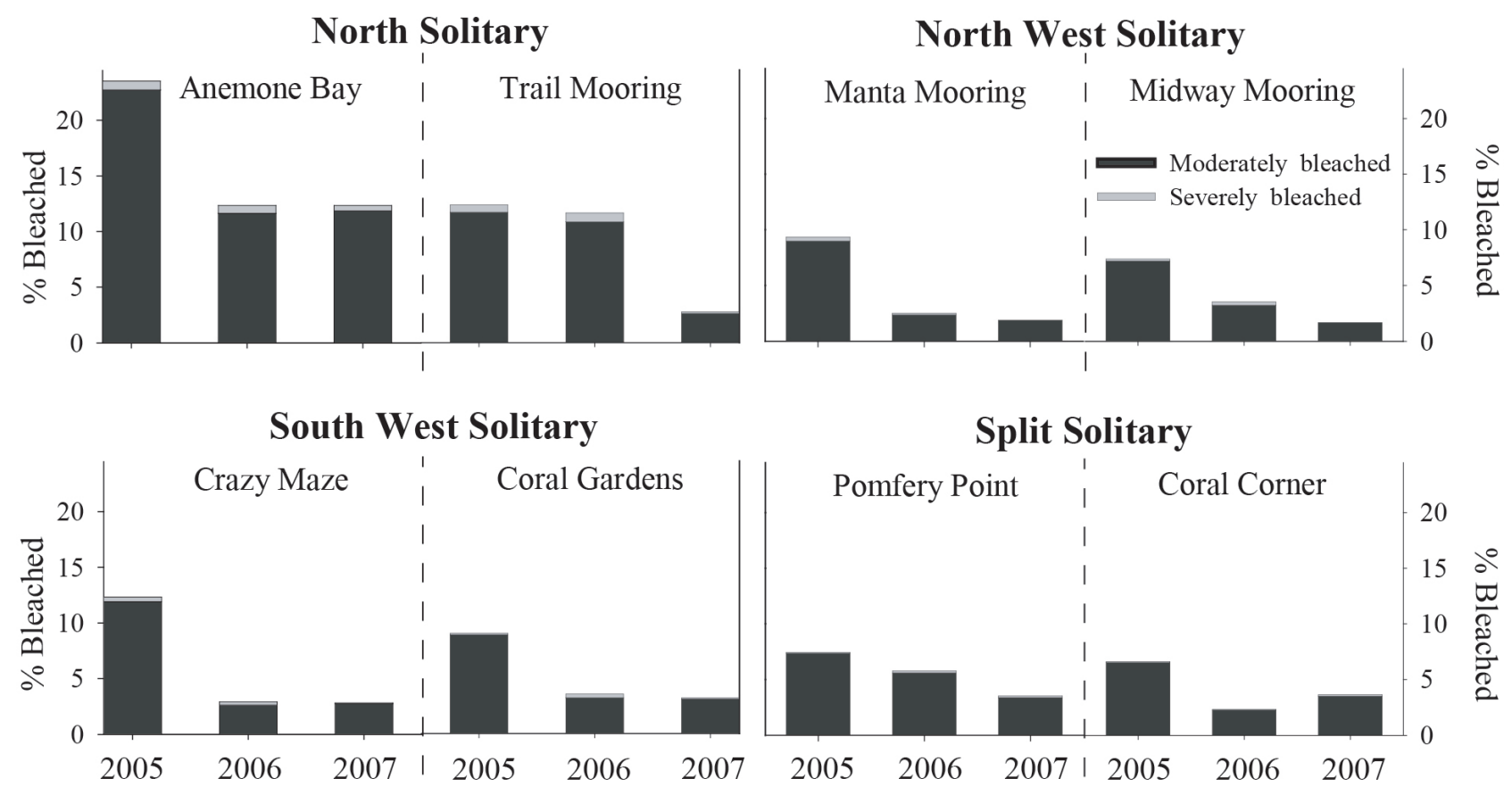

Five coral families (Acroporidae, Dendrophylliidae, Faviidae, Pocilloporidae and Poritidae) were observed with variable levels of pigmentation loss during this study. Common coral species from the families Agariciidae, Mussidae and Siderastreidae, showed no loss of pigmentation during this time. The mean proportion of total bleaching response was variable at the family, year and location levels (Figure 3). Pocilloporidae spp., notably Pocillopora damicornis and Stylophora pistillata, were frequently observed with tissue paling, particularly at the branch tips during summer surveys at all island sites. Total bleaching response (moderate and severe combined) was highest in this taxon during the 2005 summer surveys, during which time total bleaching ranged between $22.5 \pm 3.1 \%$ (NSI) and $34.6 \pm 5.8 \%$ (NWSI).

During this study, the bleaching susceptibility of dominant corals families (e.g., Dendrophylliidae, Faviidae, Pocilloporidae and Poritidae) within the SIMP was significantly higher than rarer families (e.g., Agariciidae, Mussidae and Siderastreidae) (see also [34]). This suggests that variation in bleaching susceptibility between locations may be associated with temperature and light history as well as ecological factors. This hypothesis is in accordance with Marshall and Baird [29] who indicated that environmental factors (e.g., temperature and light intensity) may explain large-scale patterns of bleaching occurrence, while small-scale patterns were determined by assemblage composition. 
Figure 3. Average proportion of bleaching response (moderate-dark grey and severe-light grey) recorded for different coral families during coral health and bleaching surveys at four island locations within the SIMP. (a) Dendrophylliidae; (b) Pocilloporidae; (c) Acroporidae; (d) Faviidae; and (e) Poritidae. Numbers above bars indicate the total number of colonies counted within each family at each location.

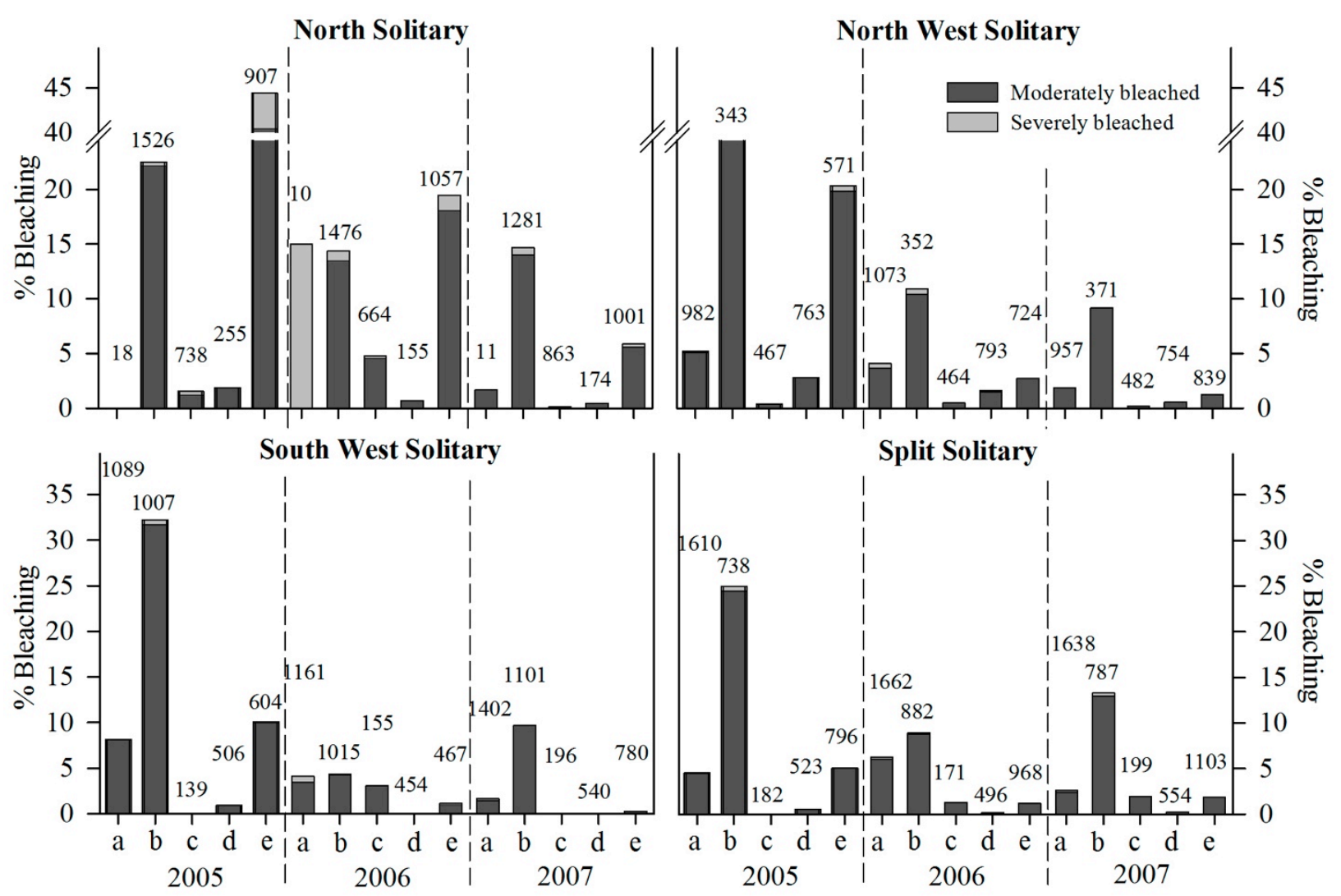

Poritidae colonies were regularly observed with decreased tissue color at all locations during summer observations, particularly at NSI, where bleaching reached $44.2 \pm 8.2 \%$ in 2005 (Figure 3). This negative response to high summer seawater temperature may explain why Porites heronensis is common in subtropical localities but rare in the tropics [35]. However, other abiotic and biotic factors need to be considered when explaining distributions patterns. Massive Porites colonies have previously shown moderate bleaching susceptibility to thermal stress [29], while branching poritids displayed significant bleaching response and associated mortality on Kenyan reefs during the 1998 mass bleaching event [28].

\subsubsection{Patterns of Family Bleaching Susceptibility in the SIMP}

Total bleaching susceptibility index (BSI) was higher at all sites during summer 2005 compared to other summer survey periods. This was confirmed by the SNK analysis, which indicated that total BSI was significantly higher during summer 2005 compared to subsequent summers $(p<0.05)$. BSI was significantly more variable at smaller spatial scales (i.e., sites within location: $\mathrm{F}_{4,192}=5.5, p=0.0003$ ) than between locations $\left(\mathrm{F}_{3,192}=4.24, p=0.0787\right)$. However, SNK contrasts showed that within location differences were only significant during summer 2005 and 2007 at NSI and at SSI in 2006. All other within location planned contrasts (9 out of 12) were not significantly different $(p>0.05)$. 
Family differences in bleaching susceptibly were apparent with an overall significant difference in BSI $\left(\mathrm{F}_{4,24}=281.1, p<0.001\right)$. There was no significant location effect, although there was a significant location by family interaction $\left(\mathrm{F}_{8,24}=26.05, p<0.001\right)$, indicating that patterns of family bleaching susceptibility were variable across all locations. Planned contrasts (SNKs), which tested for differences in coral family bleaching susceptibility within location, showed that poritids and pocilloporids were significantly more susceptible at NSI, whereas the BSI for pocilloporids was significantly higher at all other locations $(p<0.05)$, with dendrophyllids more susceptible than poritids, acroporids and faviids at the southern locations. This higher level of bleaching response at NSI did not result in any reduction in hard coral cover within the coral assemblage at this location, between 2005-2007 [34].

\subsection{Patterns of Bleaching Response in the LHIMP}

A total of 7,042 individual colonies from eleven scleractinian families were recorded at the six sites evaluated, of which 396 (5.74\%) were observed with varying degrees of pigmentation loss. The mean proportion of moderate bleaching was an order of magnitude higher than the mean proportion for the severe bleaching category. The total proportion of bleached colonies ranged between $4.68 \%$ at Comet's Hole and $6.36 \%$ at Erscott's Hole. Overall, five hard coral families (Acroporidae, Dendrophylliidae, Faviidae, Pocilloporidae, and Poritidae) were observed with reduced pigmentation (Figure 4). Bleaching was present in acroporids at all sites and ranged between 0.61 and 15.13\%. Poritids and pocilloporids were observed with varying degrees of pigmentation loss at all sites. The highest bleaching response was within the pocilloporids at the exposed Malabar Reef, where 12.77 and $3.22 \%$ of this population were moderately and severely bleached, respectively.

\subsubsection{Patterns of Family Bleaching Susceptibility in the LHIMP}

Patterns of family bleaching response tended to be similar to those observed within the SIMP, with pocilloporids and poritids consistently recorded as bleached; although the level of bleaching response in acroporids tended to be higher at LHIMP (Figures 3 and 4). Statistical analysis of BSI was only performed on the families that were present at all sites. This resulted in dendrophyllid and faviid data from the exposed sites being omitted from the analysis.

Results from the two-way ANOVA indicated that there was no significant difference in BSI between sites and between families, but there was a significant interaction between these factors $\left(\mathrm{F}_{6,54}=3.0, p=0.0045\right)$. Bleaching susceptibility index for pocilloporids was higher than for acroporids and poritids at the two exposed sites, but only significantly different at Malabar Reef $(p<0.05)$. In contrast, BSI for acroporids (Isopora cuneata and Montipora spp.) was highest at North Bay Wreck and Comet's Hole, but not significantly higher than other families at these sites.

The bleaching response of pocilloporids, notably Pocillopora damicornis and Stylophora pistillata was significantly higher than for all other families within the SIMP; this was not the case at LHIMP, where the response of this taxon was not statistically higher than other affected families. However, many partial and severely bleached Stylophora colonies were observed, particularly at Malabar Reef. These two branching species have shown high bleaching susceptibility when seawater temperatures have exceeded $30{ }^{\circ} \mathrm{C}$ at other locations, including the GBR [28,29,36]. Variation in bleaching 
susceptibility within this taxon between subtropical locations may be due to the large geographical distances and erratic larval connectivity between high latitude eastern Australian reefs. Miller and Ayre [37] found that there was a clear separation in genetic population structure in $P$. damicornis colonies sampled at LHIMP, compared to those found in the SIMP. They showed that genetic diversity of $P$. damicornis at LHIMP was more similar to northern GBR populations than colonies at similar latitudes along the east coast of mainland Australia. This genetic similarity may result in a higher thermal threshold of $P$. damicornis populations at LHIMP compared to SIMP populations, which may explain why this species is more susceptible to bleaching within the SIMP than at LHIMP. However, other intrinsic factors such as differences in zooxanthallae association may contribute to the observed location differences in pocilloporid bleaching susceptibility [38,39].

Figure 4. Average proportion of bleaching response (moderate-dark grey and severe-light grey) for different families at reefs adjacent to Lord Howe Island recorded in May 2005. (a) Dendrophylliidae; (b) Pocilloporidae; (c) Acroporidae; (d) Faviidae; (e) Poritidae; and (f) pooled total. Numbers above bars indicate total number of colonies counted within each family at each site.

\section{Lagoon Sites}
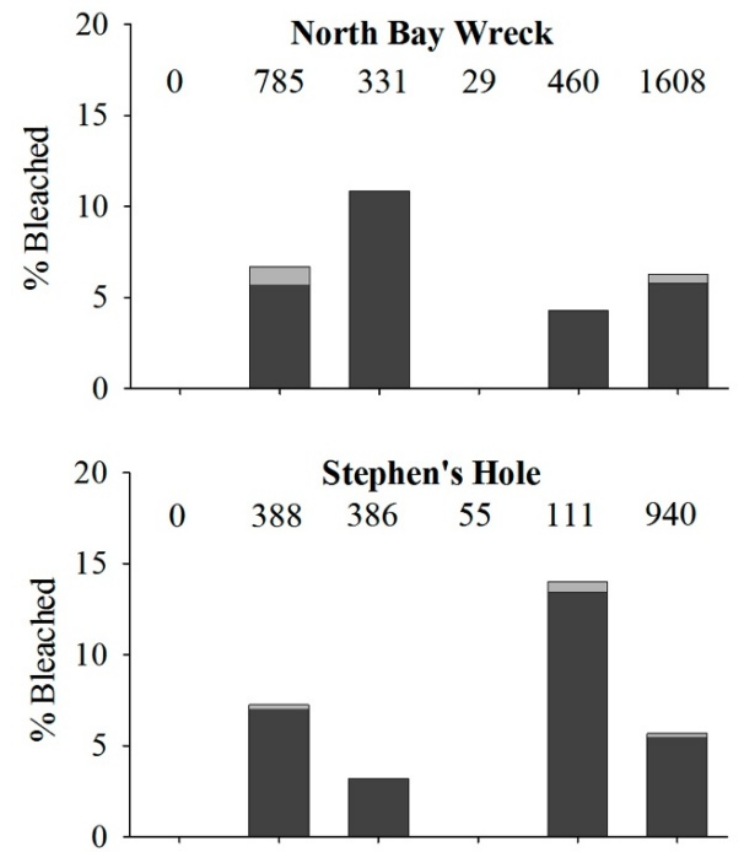

\section{Exposed Sites}

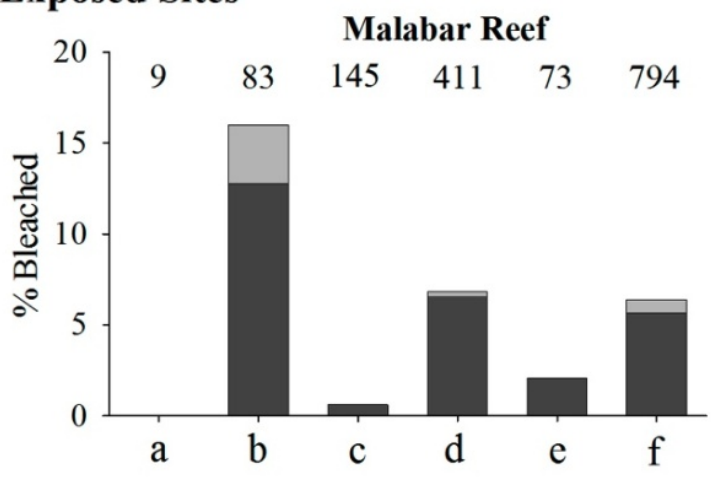

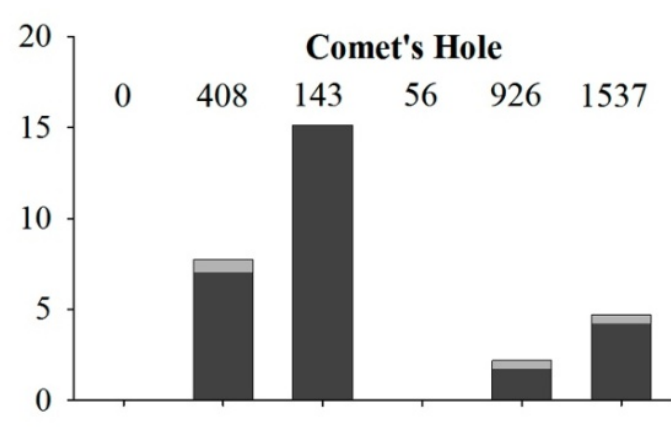
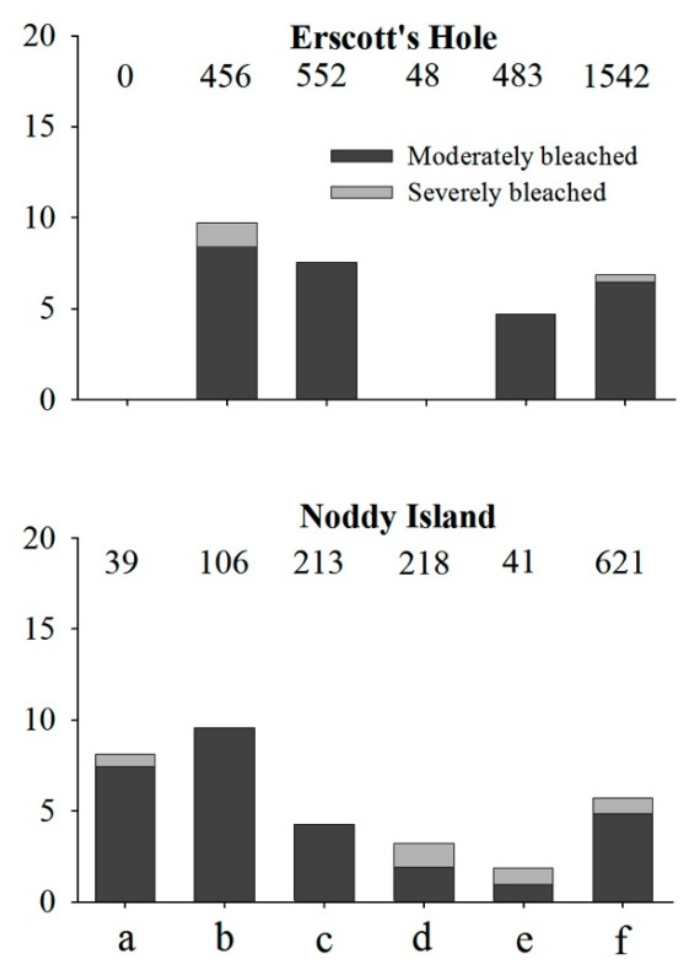
Differential bleaching susceptibility among taxa may also be attributed to many physiological factors, such as species dominance at different locations, morphological characteristics (i.e., growth form, colony size and tissue thickness) and symbiont type [28,38-41]. The numerically dominant pocilloporids and poritids observed within the SIMP and acroporids (Isopora and Montipora spp.) that dominate the fringing reef of LHIMP, were more susceptible to pigment loss relative to other taxa. These findings are consistent with previous reports of bleaching susceptibility at more northern locations [28,29]. In contrast, Turbinaria spp. (Family Dendrophylliidae) have previously been regarded as one of the least susceptible groups to bleaching throughout the GBR [29], however, at the midshelf island reefs within the SIMP (where this genus dominates), bleached colonies were regularly observed throughout the year, particularity during the warmer months. These results may indicate that if a severe bleaching event and subsequent bleaching associated mortality occurred in the future at these locations, loss of a high proportion of the coral cover of these species may occur. This has been observed at other locations where dominant coral species susceptible to thermal bleaching have significantly declined in abundance following mass bleaching episodes (e.g., [42]). Acroporids that dominate shallow inner and southern GBR reefs have succumbed to repeated bleaching episodes in recent times [29]. Other branching genera such as Seriatopora, Stylophora and Pocillopora have also succumbed to temperature bleaching stress at other locations $[1,28,43]$. If thermal stress occurs more frequently as predicted [2], a shift from branching pocilloporid and acroporid-dominated coral communities, to a reef containing larger numbers of sub-massive and encrusting growth forms, may occur at high latitude eastern Australian reefs.

\subsection{Seawater Temperature}

In situ seawater temperature recorded between 2001 and 2008 within the SIMP tended to be highly variable over small temporal and spatial scales (Figure 5). Seawater temperature data at the offshore island (NSI) was generally $1-1.5^{\circ} \mathrm{C}$ warmer than the midshelf island (SWSI), and this pattern was consistent throughout all seasons and years (Figure 5). Average daily maximum temperature was highest at NSI and ranged between 24.99 and $27.35{ }^{\circ} \mathrm{C}$ (Table 1). Maximum daily temperature was lowest during all years at SWSI, ranging between 24.32 and $25.94{ }^{\circ} \mathrm{C}$ (Table 1).

Weekly temperature fluctuations of up to $5{ }^{\circ} \mathrm{C}$ occurred consistently at the midshelf island reefs (SWSI and SSI), with an $8.4{ }^{\circ} \mathrm{C}$ differential observed at SWSI during a one-week period (Figure 5; 31 January 2008-7 February 2008). Daily temperature changes up to $4{ }^{\circ} \mathrm{C}$ day ${ }^{-1}$ were common at all locations during summer months. Summer seawater temperatures were highest during 2006 at all locations, and average daily temperature exceeded $27{ }^{\circ} \mathrm{C}$ on three occasions at NSI. However, the number of days seawater temperature exceeded $25{ }^{\circ} \mathrm{C}$ was greatest during 2002, where 52 and 33 days exceeded this measure at NSI and SWSI, respectively (Table 1). Maximum monthly mean temperatures occurred during February and March during most years at all island locations (Table 1). At NSI this measure was highest in 2006, but was highest during February 2002 at the midshelf islands. 
Figure 5. Mean daily in situ seawater temperature data collected at North Solitary Island (black line) and South West Solitary Island (grey line) between 2001 and 2008: Dotted line indicates hypothesized subtropical bleaching threshold for the SIMP.

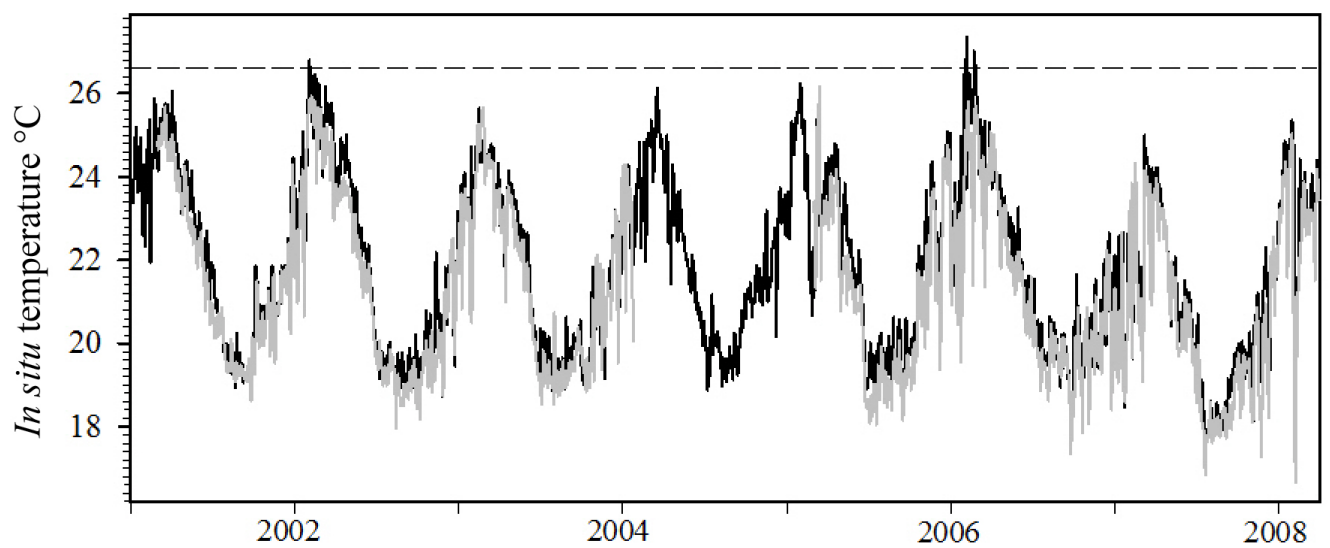

Table 1. Summary of in situ seawater temperature data collected from reefs adjacent to an offshore (North Solitary Island; NSI) and a midshelf (South West Solitary Island; SWSI) island in the SIMP. LHIMP SST data acquired from NOAA climatology [44] are shown in the absence of LHIMP in situ temperature data. DNC $=$ data not complete; $\mathrm{MMM}=$ Maximum Monthly Mean.

\begin{tabular}{|c|c|c|c|c|c|c|c|c|}
\hline \multirow[b]{2}{*}{ Location } & \multirow[b]{2}{*}{ Variable } & \multicolumn{7}{|c|}{ Years } \\
\hline & & 2001 & 2002 & 2003 & 2004 & 2005 & 2006 & 2007 \\
\hline \multicolumn{9}{|l|}{ SIMP } \\
\hline \multirow[t]{6}{*}{ NSI } & Av. daily max. & $26.1^{\circ} \mathrm{C}$ & $26.8^{\circ} \mathrm{C}$ & $25.7^{\circ} \mathrm{C}$ & $26.1^{\circ} \mathrm{C}$ & $26.2{ }^{\circ} \mathrm{C}$ & $27.4{ }^{\circ} \mathrm{C}$ & $25.0{ }^{\circ} \mathrm{C}$ \\
\hline & MMM & $25.1^{\circ} \mathrm{C}$ & $26.1^{\circ} \mathrm{C}$ & $24.3^{\circ} \mathrm{C}$ & $25.1^{\circ} \mathrm{C}$ & $24.1^{\circ} \mathrm{C}$ & $26.1^{\circ} \mathrm{C}$ & $23.4^{\circ} \mathrm{C}$ \\
\hline & warmest month & (March) & (February) & (February) & (March) & (April) & (February) & (March) \\
\hline & $\mathrm{N}^{\circ}$ days $>25^{\circ} \mathrm{C}$ & 34 & 52 & 4 & 19 & 28 & 37 & 0 \\
\hline & $\mathrm{N}^{\circ}$ days $>26^{\circ} \mathrm{C}$ & 1 & 18 & 0 & 1 & 4 & 17 & 0 \\
\hline & $\mathrm{N}^{\circ}$ days $>26.8^{\circ} \mathrm{C}$ & 0 & 3 & 0 & 0 & 0 & 6 & 0 \\
\hline \multirow[t]{6}{*}{ SWSI } & Av. daily max. & DNC & $25.9^{\circ} \mathrm{C}$ & $25.7^{\circ} \mathrm{C}$ & DNC & DNC & $25.5^{\circ} \mathrm{C}$ & $24.3{ }^{\circ} \mathrm{C}$ \\
\hline & MMM & $24.9^{\circ} \mathrm{C}$ & $25.4^{\circ} \mathrm{C}$ & $24.4^{\circ} \mathrm{C}$ & $\mathrm{DNC}$ & $23.4^{\circ} \mathrm{C}$ & $24.6^{\circ} \mathrm{C}$ & $23.0^{\circ} \mathrm{C}$ \\
\hline & warmest month & (March) & (February) & (February) & & (March) & (February) & (April) \\
\hline & $\mathrm{N}^{\circ}$ days $>25^{\circ} \mathrm{C}$ & DNC & 33 & 13 & $\mathrm{DNC}$ & $\mathrm{DNC}$ & 17 & 0 \\
\hline & $\mathrm{N}^{\circ}$ days $>26^{\circ} \mathrm{C}$ & DNC & 0 & 0 & $\mathrm{DNC}$ & $\mathrm{DNC}$ & 0 & 0 \\
\hline & $\mathrm{N}^{\circ}$ days $>26.8^{\circ} \mathrm{C}$ & DNC & 0 & 0 & DNC & $\mathrm{DNC}$ & 0 & 0 \\
\hline \multicolumn{9}{|l|}{ LHIMP } \\
\hline & Av. daily max. & 24.3 & 24.7 & 24.4 & 25.2 & 24.5 & 25.2 & 24.4 \\
\hline & MMM & $23.7^{\circ} \mathrm{C}$ & $23.9^{\circ} \mathrm{C}$ & $24.0^{\circ} \mathrm{C}$ & $24.8^{\circ} \mathrm{C}$ & $24.2^{\circ} \mathrm{C}$ & $24.7^{\circ} \mathrm{C}$ & $24.0^{\circ} \mathrm{C}$ \\
\hline & warmest month & (March) & (February) & (February) & (February) & (March) & (February) & (March) \\
\hline
\end{tabular}

Scleractinian corals within the SIMP are exposed to a varied temperature regime throughout the year, with temperatures ranging between 16 and $28{ }^{\circ} \mathrm{C}$. This high level of variation may generate evolutionary pressures to develop resilience mechanisms for the coral holobiont (zooxanthellae, bacteria, viruses and fungus associated with the coral host), enabling them to adjust to changing sea 
temperature within a short period of time. In contrast to coral reefs environments such as the GBR, seawater temperature varies considerably at both small and large time scales along the NSW coastline. Therefore, hard corals within the SIMP may require short-term physiological mechanisms that help to prevent thermal stress and damage. Homeostatic processes such as: increased production of mucus polysaccharides which contain microsporine amino acids (MAA) that absorb UVR; endosymbiont reshuffling to more heat or cool tolerant clades if multiple symbionts are associated with subtropical coral species [45]; and the production of fluorescence pigments [46], provide acclimatization and adaptive mechanisms that increase the ability of the holobiont to combat stress caused by temperature variations.

\subsection{Subtropical Bleaching Thermal Threshold}

Thermal bleaching threshold values reported in the literature [46] displayed a distinct inverse trend with latitude (Figure 6). Results from the second-order polynomial analysis indicated a significant relationship $\left(\mathrm{F}_{2,7}=175.70, p<0.0001\right)$ between bleaching thresholds and latitude; the model accounted for a high proportion of the variance in the data set (Figure $6, r^{2}=0.99$ ). Applying the equation generated by the regression procedure indicated that the hypothetical thermal bleaching threshold for corals located at $30^{\circ} \mathrm{S}$ (SIMP) and $31.5^{\circ} \mathrm{S}$ (LHIMP) are 26.8 and $26.5{ }^{\circ} \mathrm{C}$, respectively. The hypothetical bleaching threshold for the SIMP has previously been exceeded in 2002 and 2006, where average in situ daily seawater temperature at NSI exceeded this measure for a period of 3 and 6 days, respectively. However, this sea temperature threshold has not been exceeded at $10 \mathrm{~m}$ depth at the midshelf island (SWSI; Table 1).

Figure 6. Second-order polynomial plot of thermal bleaching threshold data derived from thermal threshold estimates published in Hoegh-Guldberg [2]_Jamaica, Phuket, Tahiti, Rarotonga, and northern, central and southern GBR, and Cellier and Schleyer [32]—Sodwana Bay, South Africa. Bleaching thermal stress values for regions outside these latitudes may be hypothetically extrapolated using this regression equation.

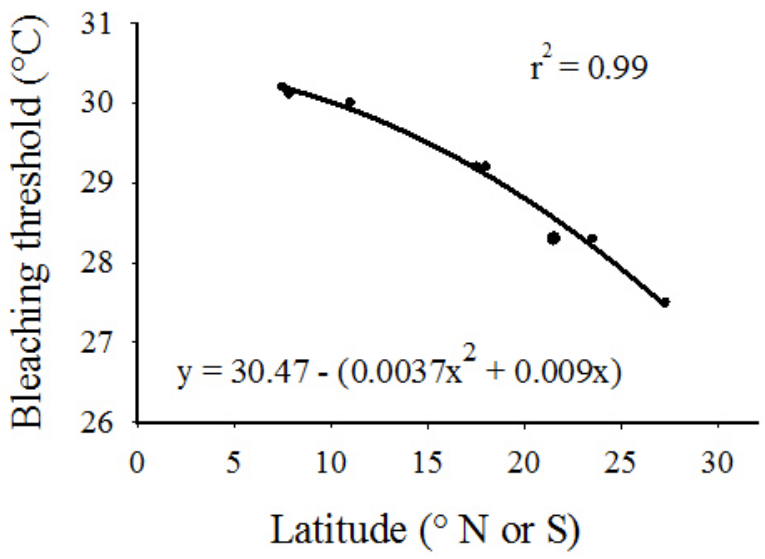

By modeling the seawater temperature data and bleaching threshold indices from other reef locations, a prediction can be made that the summer bleaching threshold within the SIMP and LHIMP are $26.8^{\circ} \mathrm{C}$ and $26.5^{\circ} \mathrm{C}$, respectively. However, as indicated above, this measure does not take into consideration seasonal differences in coral susceptibility to temperature-induced bleaching, as well as other variables such as light intensity that are known to cause bleaching in isolation or in combination 
with other parameters. It is hypothesized that thermally induced bleaching would occur throughout eastern Australia coral populations during periods when seawater temperature exceeds the predicted threshold for a period greater than four weeks (sensu $[31,47]$ ). This however, would only occur when the EAC exposes reef communities to higher than normal summer seawater temperatures for extended periods, with minimal mixing of cooler water.

Manzello et al. [48] tested the effectiveness of nine thermal indices to predict bleaching response at several locations along the Florida Keys Tract. They concluded that maximum monthly SST and the number of days above the predicted thermal threshold was the most accurate predictor of past bleaching patterns. They also reported similar trends when regressing bleaching curves with latitude and seasonal maximum SST. Other factors however, such as local small-scale temperature variations, differences in local seasonal climatic conditions, temperature history [48] and turbidity [49], also require interpretation and inclusion into the aforementioned bleaching model. Nevertheless, the high latitude bleaching model presented in this study provides a useful framework from which to advance studies on bleaching response at finer spatial scales, particularly in the context of local oceanographic conditions.

Environmental factors such as upwelling, strong currents, cloud cover, and light attenuation with increasing depth, have been reported to reduce the impact of thermal stress [32,50,51]. These extrinsic factors may be acting independently or synergistically to improve the resistance and resilience of eastern Australian subtropical coral communities to recent episodes of stress. This hypothesis is supported by Reigl and Piller's [50] study, which found that at two subtropical regions (Bahamas and South Africa), upwelled water provided a mechanism that minimized the effects of thermal stress on coral communities. They also proposed that deeper reefs at these locations were refuges for coral recruitment following bleaching events.

Localized upwelling and deep reefs are common features of benthic habitats along the east coast of northern NSW, particularly throughout the SIMP. Recent swath mapping of seabed habitats has identified reefs extending from mainland Australia to the continental shelf, and hard corals are a dominant component of midshelf exposed reefs between depths of 10-25 m at $30^{\circ} \mathrm{S}$ [49]. Small-scale localized upwelling, which are a common feature along the eastern Australian coastline [52], enable vertical mixing of cooler water with warmer equatorial EAC driven waters. This study therefore supports the hypothesis that high latitude marginal reefs found adjacent to deeper reefs, where vertical mixing between cool deeper water and shallow heated waters occurs, may provide some relief from future predicted climate change driven bleaching events [53,54]. However, upwelled seawater may also be enriched in $\mathrm{CO}_{2}$, which can exacerbate localized ocean acidification [55].

Other factors, such as limited genetic diversity in subtropical coral populations [37,56,57], reduced local reproductive capacity [58-61], sporadic long-distance recruitment [62], ocean acidification [55,63-65], and poor water quality [66] may also reduce the ability of subtropical coral communities to successfully recover from chronic or catastrophic disturbance that may result in a significant loss of coral diversity.

\subsection{Applying the High Latitude Bleaching Model-2010 LHIMP Bleaching Event}

In mid December 2009, seawater temperatures within the LHIMP lagoon began to rise above the predicted thermal threshold level $\left(26.5^{\circ} \mathrm{C}\right.$; Figure 7$)$. A bleaching warning was issued through the NOAA Coral Reef Watch Satellite Bleaching Alert System. During January 2010, a reduction in 
zooxanthellae pigmentation was observed in many coral species within the lagoon. Quantitative bleaching assessments in March 2010 showed that bleaching ranged between 50-98\% within the coral assemblages at five sites within the lagoon [67]. As the bleaching model predicted, Pocilloporid corals (Pocillopora, Stylophora and Seriatopora) and Montipora spp. severely bleached with some bleaching associated mortality observed at several sites. Additionally, Isopora cuneata and Porites spp. displayed variable pigmentation loss [67]. Data collected during the early stages of the 2010 LHI thermal anomaly supports the predictions of the subtropical bleaching model. Further research will investigate the capacity of marginal coral communities to acclimate to future predicted thermal stress events, by quantifying the ability of bleached coral species to shuffle to more thermally tolerant zooxanthellae clades.

Figure 7. In situ seawater temperature recorded at Sylph's Hole within the Lord Howe Island lagoon during the 2010 thermal bleaching event. Broken line indicates hypothetical subtropical thermal threshold at LHIMP. Temperature data acquired from AIMS website [68].

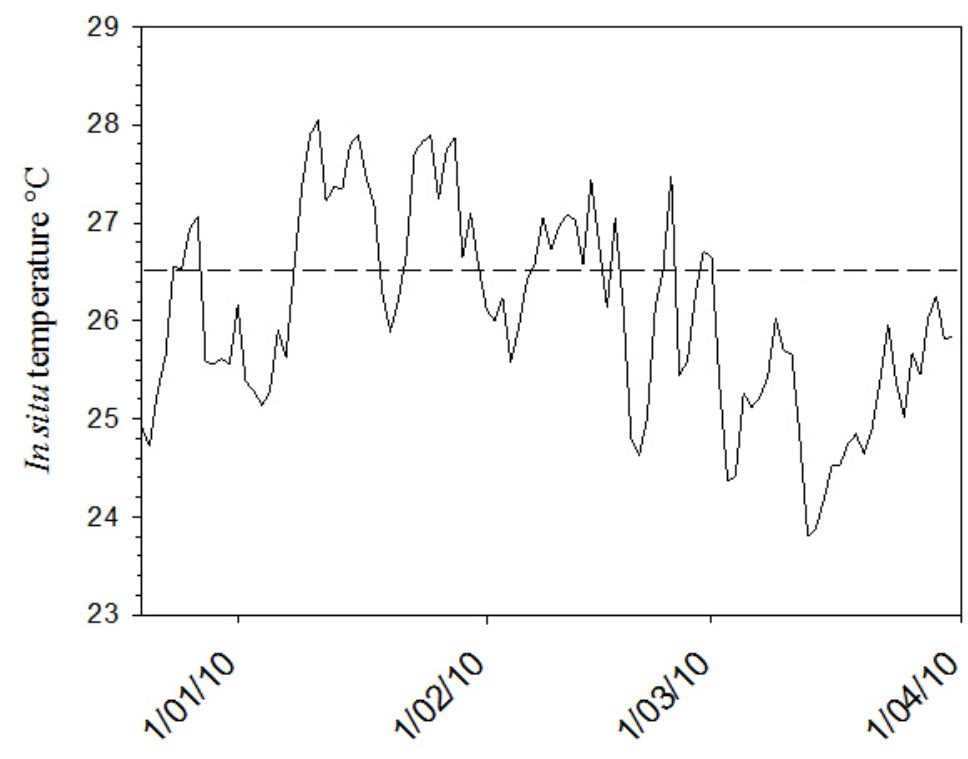

\section{Conclusions}

\subsection{High Latitude Bleaching Model}

The high latitude bleaching model presented in this study predicts that at eastern Australian subtropical locations, some scleractinian coral genera from the families Acroporidae (e.g., Isopora and Montipora), Dendrophylliidae (e.g., Turbinaria), Pocilloporidae (e.g., Pocillopora and Stylophora) and Poritidae (e.g., Porites) will be more susceptible to thermal stress than coral genera from the families Faviidae (e.g., Goniastrea and Favites), Mussidae (e.g., Acanthastrea) and Siderastreidae (e.g., Psammocora). In light of predicted increases in seawater temperature (see [2]) we hypothesize that seawater temperatures that exceed $26.5^{\circ} \mathrm{C}$ and $26.8^{\circ} \mathrm{C}$ within the LHIMP and SIMP, respectively, for a period greater than four weeks (see [31,47]), will result in extensive coral bleaching, with associated mortality determined by the duration of the thermal anomaly and the intensity of insolation. It is predicted that future repeated bleaching events may lead to a decline in live hard coral cover of dominant coral species that have limited northern distributions, with a subsequent increase in the 
relative abundance of other rarer coral taxa. Coral species diversity at these locations may not increase; rather a shift in the coral assemblage is predicted to occur through time [69].

\section{Acknowledgments}

The University of New England (UNE), Lord Howe Island Marine Park and the Solitary Islands Marine Park, NSW Department of Primary Industries, provided financial support for this study. We thank all colleagues from Southern Cross University (National Marine Science Centre) and UNE who assisted with fieldwork, including Steve Smith, Matthew Harrison, Matt Beattie, Scott Godwin, Rod Forbes, Gary Shipley and Andrew Cox. We acknowledge Ray Berkelmans (Australian Institute of Marine Science) and Hamish Malcolm (SIMP) for assistance with in situ temperature data. Finally, we thank the two anonymous reviewers who provided helpful feedback, which has improved this manuscript.

\section{References}

1. Loya, Y.; Sakai, K.; Yamazato, K.; Nakano, Y.; Sambali, H.; van Woesik, R. Coral bleaching: The winners and the losers. Ecol. Lett. 2001, 4, 122-131.

2. Hoegh-Guldberg, O. Climate change, coral bleaching and the future of the world's coral reefs. Mar. Freshw. Res. 1999, 50, 839-866.

3. Berkelmans, R.; de'ath, G.; Kininmonth, S.; Skirving, W.J. A comparison of the 1998 and 2002 coral bleaching events on the Great Barrier Reef: Spatial correlation, patterns, and predictions. Coral Reefs 2004, 23, 74-83.

4. Lesser, M.P. Oxidative stress causes coral bleaching during exposure to elevated temperatures. Coral Reefs 1997, 16, 187-192.

5. Glynn, P.W. Coral reef bleaching: Facts, hypotheses and implications. Glob. Change Biol. 1996, 2, 495-509.

6. Brown, B.E. Coral bleaching: Causes and consequences. Coral Reefs 1997, 16, 129-138.

7. Hoegh-Guldberg, O.; Smith, G.J. The effect of sudden change in temperature, light and salinity on the population density and export of zooxanthellae from the reef corals Stylophora pistillata Esper and Seriatopora hystrix Dana. J. Mar. Biol. Ecol. 1989, 129, 279-303.

8. Coles, S.L.; Jokiel, P.L. Synergistic effects of temperature, salinity and light on the hermatypic coral Montipora verrucosa. Mar. Biol. 1978, 49, 187-195.

9. Van Woesik, R.; de Vantier, L.M.; Glazebrook, J.S. Effects of Cyclone 'Joy' on nearshore coral communities of the Great Barrier Reef. Mar. Ecol. Prog. Ser. 1995, 128, 261-270.

10. Brown, B.E.; Dunne, R.P.; Scoffin, T.P.; le Tissier, M.D.A. Solar damage in intertidal corals. Mar. Ecol. Prog. Ser. 1994, 105, 219-230.

11. Lesser, M.P. Depth-dependent photoacclimatization to solar ultraviolet radiation in the Caribbean coral Montastraea faveolata. Mar. Ecol. Prog. Ser. 2000, 192, 137-151.

12. Fitt, W.K.; Brown, B.E.; Warner, M.E.; Dunne, R.P. Coral bleaching: Interpretation of thermal tolerance limits and thermal thresholds in tropical corals. Coral Reefs 2001, 20, 51-65. 
13. Jones, R.J.; Kildea, T.; Hoegh-Guldberg, O. PAM chlorophyll fluorometry: A new in situ technique for stress assessment in scleractinian corals, used to examine the effects of cyanide from cyanide fishing. Mar. Pollut. Bull. 1999, 38, 864-874.

14. Hoegh-Guldberg, O.; Salvat, B. Periodic mass-bleaching and elevated sea temperatures: Bleaching of outer reef slope communities in Moorea, French Polynesia. Mar. Ecol. Prog. Ser. 1995, 121, 181-190.

15. Kushmaro, A.; Rosenberg, E.; Fine, M.; Ben Haim, Y.; Loya, Y. Effect of temperature on bleaching of the coral Oculina patagonica by Vibrio AK-1. Mar. Ecol. Prog. Ser. 1998, 171, 131-137.

16. Banin, E.; Ben-Haim, Y.; Israely, T.; Loya, Y.; Rosenberg, E. Effect of the environment on the bacterial bleaching of corals. Water Air Soil Pollut. 2000, 123, 337-352.

17. Rosenberg, E.; Ben-Haim, Y. Microbial diseases of corals and global warming. Environ. Microbiol. 2002, 4, 318-326.

18. Wilkinson, C.R. Global and local threats to coral reef functioning and existence: Review and predictions. Mar. Freshw. Res. 1999, 50, 867-878.

19. Wilkinson, C.R. Status of Coral Reefs of the World: 2008; AIMS: Townsville QLD, Australia, 2008; p. 296.

20. Edgar, R.J.; Malcolm, H.; Dalton, S. Coral Bleaching in the Solitary Islands Marine Park, NSW; Technical data report; NSW Marine Parks Authority: Coffs Harbour NSW, Australia, 2003; pp. 1-41.

21. Kitchener, T. Bleaching of Hard Corals at Lord Howe Island, NSW, Coinciding with the 1998 Mass Bleaching Event; Southern Cross University: Lismore NSW, Australia, 1998; p. 99.

22. Berkelmans, R.; Willis, B.L. Seasonal and local spatial patterns in the upper thermal limits of corals on the inshore central Great Barrier Reef. Coral Reefs 1999, 18, 219-228.

23. Harriott, V.J.; Harrison, P.L.; Banks, S.A. The coral communities of Lord Howe Island. Mar. Freshw. Res. 1995, 46, 457-465.

24. Harriott, V.J.; Smith, S.D.A.; Harrison, P.L. Patterns of coral community structure of subtropical reefs in the Solitary Islands Marine Reserve, eastern Australia. Mar. Ecol. Prog. Ser. 1994, 109, 67-76.

25. Veron, J.E.N.; Done, T.J. Corals and coral communities of Lord Howe Island. Aust. J. Freshw. Res. 1979, 30, 203-236.

26. Veron, J.E.N.; How, R.A.; Done, T.J.; Zell, L.D.; Dodkin, M.J.; O’Farell, A.F. Corals of the Solitary Islands, Central New South Wales. Aust. J. Freshw. Res. 1974, 25, 193-208.

27. Dalton, S.J.; Harrison, M.; Carroll, A.G.; Smith, S.D.A.; Pereg, L.; Cairns, S.C. Spatial and temporal patterns of Australian subtropical white syndrome at eastern Australian reefs: Host range, prevalence and progression of tissue necrosis. In Handbook of Disease Outbreaks: Prevention, Detection and Control; Albin, H., Borg, G., Eds.; Nova Science Publishers Inc.: New York, NY, USA, 2010; pp. 187-210.

28. McClanahan, T.R.; Baird, A.H.; Marshall, P.A.; Toscano, M.A. Comparing bleaching and mortality responses of hard corals between southern Kenya and the Great Barrier Reef, Australia. Mar. Pollut. Bull. 2004, 48, 327-335.

29. Marshall, P.A.; Baird, A.H. Bleaching of corals on the Great Barrier Reef: Differential susceptibilities among taxa. Coral Reefs 2000, 19, 155-163. 
30. Malcolm, H.A.; Davies, P.L.; Jordan, A.; Smith, S.D.A. Variation in sea temperature and the East Australian current in the Solitary Islands region between 2001-2008. Deep Sea Res. Part II: Top. Stud. Oceanogr. 2011, 58, 616-627.

31. Strong, A.E.; Liu, G.; Meyer, J.; Hendee, J.; Sasko, D. Coral reef watch 2002. Bull. Mar. Sci. 2004, 75, 259-268.

32. Celliers, L.; Schleyer, M.H. Coral bleaching on high-latitude marginal reefs at Sodwana Bay, South Africa. Mar. Pollut. Bull. 2002, 44, 1380-1387.

33. Weeks, S.J.; Anthony, K.R.N.; Bakun, A.; Feldman, G.C.; Hoegh-Guldberg, O. Improved predictions of coral bleaching using seasonal baselines and higher spatial resolution. Limnol. Oceanogr. 2008, 53, 1369-1375.

34. Dalton, S.J. Stressors of Eastern Australian Subtropical Corals: Australian Subtropical White Syndrome and Coral Bleaching. Ph.D. Dissertation; University of New England: Armidale NSW, Australia, 2009.

35. Veron, J.E.N. Corals of the World, Volume 2; Australian Institute of Marine Science: Townsville QLD, Australia, 2000; Volume 2, p. 429.

36. Vargas-Angel, B.; Zapata, F.; Hernandez, H.; Jimenez, J.M. Coral and coral reefs responses to the 1997-1998 El Nino event on the Pacific Coast of Colombia. Bull. Mar. Sci. 2001, 69, 111-132.

37. Miller, K.J.; Ayre, D.J. Protection of genetic diversity and maintenance of connectivity among reef corals within marine protected areas. Conserv. Biol. 2008, 22, 1245-1254.

38. Wicks, L.C.; Hill, R.; Davy, S.K. The influence of irradiance on tolerance to high and low temperature stress exhibited by Symbiodinium in the coral, Pocillopora damicornis, from the high-latitude reef of Lord Howe Island. Limnol. Oceanogr. 2010, 55, 2476-2486.

39. Bhagooli, R.; Hidaka, M. Comparison of stress susceptibility of in hospite and isolated zooxanthellae among five coral species. J. Exp. Mar. Biol. Ecol. 2003, 291, 181-197.

40. LaJeunesse, T.C.; Loh, W.K.W.; van Woesik, R.; Hoegh-Guldberg, O.; Schmidt, G.W.; Fitt, W.K. Low symbiont diversity in southern Great Barrier Reef corals, relative to those of the Caribbean. Limnol. Oceanogr. 2003, 48, 2046-2054.

41. Berkelmans, R.; van Oppen, M.J.H. The role of zooxanthellae in the thermal tolerance of corals: A 'nugget of hope' for coral reefs in an era of climate change. Proc. R. Soc. B 2006, 273, 2305-2312.

42. Goreau, T.; McClanahan, T.; Hayes, R.; Strong, A. Conservation of coral reefs after the 1998 global bleaching event. Conserv. Biol. 2000, 14, 5-15.

43. Baird, A.H.; Marshall, P.A. Mass bleaching of corals on the Great Barrier Reef. Coral Reefs 1998, $17,376$.

44. National Oceanic and Atmospheric Administration (NOAA). Physical Oceanography Distributed Active Archive Center, Bulk Sea Surface Temperature. Available online: http://podaac.jpl.nasa. gov/dataset/ (accessed on 1 March 2008).

45. Chen, C.A.; Yang, Y.; Wei, N.V.; Tsai, W.; Fang, L. Symbiont diversity in scleractinian corals from tropical reefs and subtropical non-reef communities in Taiwan. Coral Reefs 2005, 24, 11-22.

46. Salih, A.; Larkum, A.; Cox, G.; Kuhl, M.; Hoegh-Guldberg, O. Fluorescent pigments in corals are photoprotective. Nature 2000, 408, 850-853. 
47. Lui, G.; Strong, A. E.; Skriving, W. J.; Arzayus, L. F. Overview of NOAA coral reef watch program's near-real-time satellite global coral bleaching monitoring program, In Proceedings of the 10th International Coral Reef Symposium, Okinawa, Japan, 28 June-2 July 2004; Suzuki, Y., Nakamori, T., Hidaka, M., Kayanne, H., Casareto, B.E., Nadaoka, K., Yamano, H., Tsuchiya, M., Eds.; Japan Coral Reef Society: Okinawa, Japan, 2006; pp. 1783-1793.

48. Manzello, D.; Berkelmans, R.; Hendee, J. Coral bleaching indices and thresholds for the Florida Reef Tract, and St. Croix, US Virgin Islands. Mar. Pollut. Bull. 2007, 54, 1923-1931.

49. Jokiel, P.L.; Brown, E.K. Global warming, regional trends and inshore environmental conditions influence coral bleaching in Hawaii. Glob. Change Biol. 2004, 10, 1627-1641.

50. Riegl, B.; Piller, W.E. Possible refugia for reefs in times of environmental stress. Int. J. Earth Sci. 2003, 92, 520-531.

51. West, J.M.; Salm, R.V. Resistance and resilience to coral bleaching: Implications for coral reef conservation and management. Conserv. Biol. 2003, 17, 956-967.

52. NSW Marine Parks Authority. Seabed Habitat Mapping in the Solitary Islands Marine Park and Jervis Bay Marine Park; NSW Marine Parks Authority: Hurstville, Australia, 2010; p. 58.

53. Roughan, M.; Middleton, J.H. On the East Australian Current: Variability, encroachment, and upwelling. J. Geophys. Res. 2004, 109, C07003.

54. Roughan, M.; Oke, P.R.; Middleton, J.H. A modelling study of the climatological current field and the trajectories of upwelled particles in the East Australian Current. Am. Meteorol. Soc. 2003, 33, 2551-2564.

55. Manzello, D.P. Ocean acidification hotspots: Spatiotemporal dynamics of the seawater $\mathrm{CO}_{2}$ system of eastern Pacific coral reefs. Limnol. Oceanogr. 2010, 55, 239-248.

56. Ayre, D.J.; Hughes, T.P. Climate change, genotypic diversity and gene flow in reef-building corals. Ecol. Lett. 2004, 7, 273-278.

57. Noreen, A.M.E.; Harrison, P.L.; van Oppen, M.J.H. Genetic diversity and connectivity in a brooding reef coral at the limit of its distribution. Proc. R. Soc. B 2009, 276, 3927-3935.

58. Wilson, J.R. Reproduction and Larval Ecology of Broadcast Spawning Corals at the Solitary Islands, Eastern Australia. Ph.D. Dissertation; Southern Cross University: Lismore NSW, Australia, 1998.

59. Wilson, J.R.; Harrison, P.L. Post-settlement mortality and growth of newly settled reef corals in a subtropical environment. Coral Reefs 2005, 24, 418-421.

60. Wilson, J.R.; Harrison, P.L. Sexual reproduction in high latitude coral communities at the Solitary Islands, Eastern Australia. In Proceedings of the 8th International Coral Reef Symposium, Panama City, FL, USA, 24-29 June 1996; Lessios, H.A., Macintyre, I.G., Eds.; Smithsonian Tropical Research Institute: Panama City, FL, USA, 1997; pp. 533-538.

61. Wilson, J.R.; Harrison, P.L. Spawning patterns of scleractinian corals at the Solitary Islands-A high latitude coral community in Eastern Australia. Mar. Ecol. Prog. Ser. 2003, 260, 115-123.

62. Harriott, V.J.; Banks, S.A. Recruitment of scleractinian corals in the Solitary Islands Marine Reserve, a high latitude coral-dominated community in eastern Australia. Mar. Ecol. Prog. Ser. 1995, 123, 155-161. 
63. Anthony, K.R.N.; Kline, D.I.; Diaz-Pulido, G.; Dove, S.; Hoegh-Guldberg, O. Ocean acidification causes bleaching and productivity loss in coral reef builders. Proc. Natl. Acad. Sci. 2008, 105, 17442-17446.

64. Kleypas, J.A.; Yates, K.K. Coral reefs and ocean acidification. Oceanography 2009, 22, 108-117.

65. Veron, J.E.N. Ocean acidification and coral reefs: An emerging big picture. Diversity 2011, 3, 262-274.

66. Wooldridge, S.A. Water quality and coral bleaching thresholds: Formalising the linkage for the inshore reefs of the Great Barrier Reef, Australia. Mar. Pollut. Bull. 2009, 58, 745-751.

67. Harrison, P.L.; Dalton, S.J.; Carroll, A.G. Extensive coral bleaching on the world's southernmost coral reef at Lord Howe Island, Australia. Coral Reefs 2011, 30, 775.

68. AIMS Data Centre; Australian Institute of Marine Science (AIMS): Queensland, Australia, 2011. Available online: http://data.aims.gov.au/aimsrtds/map.xhtml (accessed on 1March 2008).

69. Precht, W.F.; Aronson, R.B. Climate flickers and range shifts of reef corals. Front. Ecol. Envrion. 2004, 2, 307-314.

(C) 2011 by the authors; licensee MDPI, Basel, Switzerland. This article is an open access article distributed under the terms and conditions of the Creative Commons Attribution license (http://creativecommons.org/licenses/by/3.0/). 